\title{
Correction to: Immunomodulatory effects of a new whole ingredients extract from Astragalus: a combined evaluation on chemistry and pharmacology
}

Zhi Xin Li $i^{1}$, Guan Ding Zhao', Wei Xiong ${ }^{1}$, Ke Gang Linghu', Qiu Shuo Ma', Wai San Cheang ${ }^{1}$, Hua $Y u^{1,2,3,4^{*}}$ a and Yitao Wang ${ }^{1,5^{*}}$

\section{Correction to: Chin Med (2019) 14:12}

https://doi.org/10.1186/s13020-019-0234-0

Following the publication of the original article [1], it was noted that Table 1 is missing.

The table and caption have been included in this correction, and the original article has been corrected.

\begin{abstract}
Shenzhen Research Center, Shenzhen, Guangdong, China. ${ }^{3}$ School of Chinese Medicine, Hong Kong Baptist University, Kowloon Tong, Hong Kong, China. ${ }^{4}$ Institute of Chinese Medical Sciences, University of Macau, Room 8008, Building N22, Avenida da Universidade, Taipa, Macao SAR, China. ${ }^{5}$ Institute of Chinese Medical Sciences, University of Macau, Room 1050, Building N22, Avenida da Universidade, Taipa, Macao SAR, China.
\end{abstract}

Published online: 06 May 2021

Table 1 Extraction amounts ( $\mathrm{g} / 100 \mathrm{~g}$ herb) of main compounds in different Astragalus extracts

\begin{tabular}{|c|c|c|c|c|c|c|c|}
\hline \multirow[t]{2}{*}{ Extract } & \multirow{2}{*}{$\begin{array}{l}\text { Total polysaccharides } \\
\text { (g/100 g herb) }\end{array}$} & \multicolumn{2}{|c|}{ Saponin (g/100 g herb) } & \multicolumn{4}{|c|}{ Flavonoid (g/100 g herb) } \\
\hline & & Total & Astra IV & $\mathrm{FI}$ & $F \|$ & FIIII & FIV \\
\hline WIE & $12.87 \pm 0.032$ & $0.52 \pm 0.022$ & $0.011 \pm 0.001$ & $0.010 \pm 0.002$ & $0.003 \pm 0.001$ & $0.039 \pm 0.001$ & $0.013 \pm 0.001$ \\
\hline WAE & $11.52 \pm 0.027$ & $0.25 \pm 0.019$ & $0.012 \pm 0.001$ & $0.004 \pm 0.001$ & $0.001 \pm 0.001$ & $0.019 \pm 0.003$ & $0.004 \pm 0.001$ \\
\hline
\end{tabular}

Astra IV Astragaloside IV, FI calycosin-7-O- $\beta$-d-glucoside, FII ononin; FIII calycosin; and FIV formononetin

WIE whole ingredients extract, WAE water extract

Author details

${ }^{1}$ Institute of Chinese Medical Sciences, State Key Laboratory of Quality Research in Chinese Medicine, University of Macau, Macao, China. ${ }^{2}$ HKBU

The original article can be found online at https://doi.org/10.1186/s13020019-0234-0.

*Correspondence: yuhuayu@vip.sina.com; ytwang@um.edu.mo

${ }^{4}$ Institute of Chinese Medical Sciences, University of Macau, Room 8008, Building N22, Avenida da Universidade, Taipa, Macao SAR, China

${ }^{5}$ Institute of Chinese Medical Sciences, University of Macau, Room 1050, Building N22, Avenida da Universidade, Taipa, Macao SAR, China

Full list of author information is available at the end of the article

\section{Reference}

1. Li ZX, Zhao GD, Xiong W, Linghu KG, Ma QS, San Cheang W, Yu H, Wang Y. Immunomodulatory effects of a new whole ingredients extract from Astragalus: a combined evaluation on chemistry and pharmacology. Chin Med. 2019;14:12.

\section{Publisher's Note}

Springer Nature remains neutral with regard to jurisdictional claims in published maps and institutional affiliations.

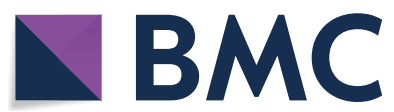

(c) The Author(s) 2021. This article is licensed under a Creative Commons Attribution 4.0 International License, which permits use, sharing, adaptation, distribution and reproduction in any medium or format, as long as you give appropriate credit to the original author(s) and the source, provide a link to the Creative Commons licence, and indicate if changes were made. The images or other third party material in this article are included in the article's Creative Commons licence, unless indicated otherwise in a credit line to the material. If material is not included in the article's Creative Commons licence and your intended use is not permitted by statutory regulation or exceeds the permitted use, you will need to obtain permission directly from the copyright holder. To view a copy of this licence, visit http://creativecommons.org/licenses/by/4.0/. The Creative Commons Public Domain Dedication waiver (http://creativecommons.org/publicdomain/zero/1.0/) applies to the data made available in this article, unless otherwise stated in a credit line to the data. 